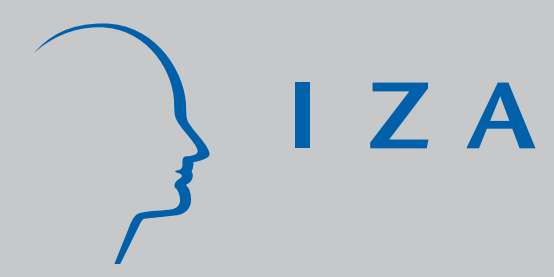

IZA DP No. 167

Earnings Inequality, Returns to Education and Immigration into Ireland

Alan Barrett

John FitzGerald

Brian Nolan

June 2000 


\title{
Earnings Inequality, Returns to Education and Immigration into Ireland
}

\author{
Alan Barrett \\ Economic and Social Research Institute, Dublin and IZA, Bonn \\ John FitzGerald \\ Economic and Social Research Institute, Dublin \\ Brian Nolan \\ Economic and Social Research Institute, Dublin \\ Discussion Paper No. 167 \\ June 2000 \\ IZA \\ P.O. Box 7240 \\ D-53072 Bonn \\ Germany \\ Tel.: +49-228-3894-0 \\ Fax: +49-228-3894-210 \\ Email: iza@iza.org
}

This Discussion Paper is issued within the framework of IZA's research area Mobility and Flexibility of Labor Markets. Any opinions expressed here are those of the author(s) and not those of the institute. Research disseminated by IZA may include views on policy, but the institute itself takes no institutional policy positions.

The Institute for the Study of Labor (IZA) in Bonn is a local and virtual international research center and a place of communication between science, politics and business. IZA is an independent, nonprofit limited liability company (Gesellschaft mit beschränkter Haftung) supported by the Deutsche Post AG. The center is associated with the University of Bonn and offers a stimulating research environment through its research networks, research support, and visitors and doctoral programs. IZA engages in (i) original and internationally competitive research in all fields of labor economics, (ii) development of policy concepts, and (iii) dissemination of research results and concepts to the interested public. The current research program deals with (1) mobility and flexibility of labor markets, (2) internationalization of labor markets and European integration, (3) the welfare state and labor markets, (4) labor markets in transition, (5) the future of work, (6) project evaluation and (7) general labor economics.

IZA Discussion Papers often represent preliminary work and are circulated to encourage discussion. Citation of such a paper should account for its provisional character. 
IZA Discussion Paper No. 167

June 2000

\title{
ABSTRACT \\ Earnings Inequality, Returns to Education and Immigration into Ireland*
}

Increasing earnings inequality has been an important feature of the US and UK labour markets in recent years. The increase appears to be related to an increased demand for skilled labour and an increase in the returns to education. In this paper we examine what has happened to earnings inequality and the returns to education in Ireland between 1987 and 1997 . We find that while both increased between 1987 and 1994, the increases slowed dramatically between 1994 and 1997. This is somewhat surprising as the exceptional growth in the Irish economy occurred from 1994 on. We look to immigration as being a contributing factor to this pattern because a large group of skilled workers flowed into the Irish labour market between 1994 and 1997. We develop a model of the Irish labour market and use it to simulate the impact of an increase in skilled labour. The simulation suggests that immigration did indeed reduce earnings inequality. This result is an interesting corollary to work from the US that shows the immigration of unskilled workers increasing earnings inequality.

JEL Classification: J61

Keywords: Earnings inequality, returns to education, immigration, Ireland

\author{
Alan Barrett \\ Economic and Social Research Institute \\ 4, Burlington Road \\ Dublin 4 \\ Ireland \\ Tel.: +353-1 6689984 ext. 441 \\ Fax. +353-1668 6231 \\ Email: Alan.Barrett@esri.ie
}

\footnotetext{
* The data used are from household surveys conducted by the ESRI so we are grateful to Brendan Whelan and James Williams of the ESRI who were responsible for the survey design, data collection and database creation. Alan Barrett would like to acknowledge the financial support of the EU's TSER programme, grant no. SOE2-CT97-3052.
} 


\section{INTRODUCTION}

A central feature of the global economic environment against which recent Ireland's recent economic success has to be set is increasing earnings inequality within some major industrialised countries. Increasing earnings dispersion has been pronounced in the United Kingdom and the United States, and has given rise to a great deal of research there. The common factor in this research is the emphasis placed on rising returns to education and skill. ${ }^{1}$ There has been less agreement on why this has happened, some for example attributing it to a shift in demand towards more skilled labour due to factors such as skill-biased technical change (Katz and Murphy, 1992) and others highlighting globalisation and competition from developing countries (Wood, 1994). ${ }^{2}$

Some industrialised countries have in fact experienced much smaller increases in inequality than the USA and the UK, while others again have maintained stability in their earnings distributions (OECD, 1993 and 1996). This has focused attention on the role of institutional factors. Countries such as Germany and the Netherlands that have seen little or no increase in earnings inequality have some form of centralized wage bargaining. This has led to the hypothesis that these wage setting institutions were the primary factor limiting the growth in inequality in those countries. ${ }^{3}$ Labour market deregulation and declining union membership

\footnotetext{
${ }^{1}$ See for example Gosling, Machin and Meghir (1994) and Schmitt (1995) for the UK, Levy and Murnane (1992) and Juhn, Murphy and Pierce (1993) for the USA

${ }^{2}$ US studies assessing such explanations include Bound and Johnson (1992), Borjas and Ramey (1994), and Burtless (1995).

${ }^{3}$ The role of institutional versus other factors in producing cross-country variation in the level and trends in earnings dispersion is discussed in for example Freeman and Katz (1995), Blau and Kahn (1996), and Gottschalk and Joyce (1997).
} 
are widely seen to have played some role in widening dispersion in the UK, particularly the virtual elimination of minimum wages through the abolition of the Wages Councils (Gosling and Machin 1995 and Machin 1997), the decline of unions, and changes in collective bargaining arrangements (Leslie and $\mathrm{Pu}$ 1996). Declines in unionisation and in the real value of the minimum wage have also been advanced as important factors in rising US earnings dispersion by, for example, Freeman (1993), DiNardo, Fortin and Lemieux (1996), and DiNardo and Lemieux (1997).

Against this background Ireland offers a particularly interesting comparative case-study. As a small and extremely open economy, external influences should be even more important than in for example the UK, much less the USA. Unlike those countries, however, the strength of labour market and associated institutions has been increasing rather than declining. Over the period on which we concentrate Ireland has been characterised by highly centralised wage bargaining. In addition, minimum wage coverage has widened and welfare benefits have provided a floor for the unemployed. Finally, the supply of skilled labour has been increasing very rapidly but so has the demand, fuelled by inward direct investment (Barrett, Callan and Nolan, 1999a).

In this paper, we firstly look at the trend in earnings inequality in Ireland from 1987 to 1997 . It will be seen that while there was a rapid increase in inequality between 1987 and 1994, this trend slowed dramatically between 1994 and 1997. As the high GNP growth rates of recent years began in $1994^{4}$, this is would appear to indicate that growth itself has not been responsible for increasing inequality. Given this pattern we go on to look at the trend in the returns to

\footnotetext{
${ }^{4}$ Growth rates in GNP have been around 7 percent since 1994.
} 
education. We find that the pattern observed in earnings inequality is repeated; in particular, while returns to education rose between 1987 and 1994, the evidence suggests that the returns were stable, or may even have fallen, between 1994 and 1997.

We then focus on one possible reason for the observed patterns. Borjas, Freeman and Katz (1997) have suggested that the increase in earnings inequality in the United States can be partly explained by the immigration of unskilled workers. As Ireland has experienced an inflow of skilled workers in the mid-1990s (Barrett and Trace 1998), this raises the possibility that the observed trend in earnings inequality in the mid 1990s is related to immigration. We test this hypothesis by simulating the effect of an increase in the supply of skilled labour using a simple model of the Irish labour market. The results suggest that the skilled inward migration did reduce earnings inequality. As such, our findings are an interesting corollary to the findings of Borjas, Freeman and Katz (1997).

\section{THE DISTRIBUTION OF EARNINGS IN IRELAND}

In analysing the distribution of earnings across individual earners, the accounting period adopted can make a considerable difference to the extent of dispersion one observes. Hourly earnings, weekly earnings, earnings over a full year, or indeed lifetime earnings are all distinct measures and may show different patterns. Weekly earnings will be affected both by the hourly rate of pay and by the number of hours worked, annual earnings by the number of weeks spent in work as well as the weekly rate, and lifetime earnings by how much time one spends in work as well as the evolution of the annual rate of pay over the lifecycle. Each of these provides valuable information, and the choice of measure will depend both on the issue at hand and the available data. In analysing the distribution of earnings, a focus on hourly earnings provides the most direct measure of differences in pay rates abstracting from 
variations in time spent working. It is also common practice in this context to examine the distribution of weekly earnings for full-time employees only, and that of annual earnings among full-time employees who have been working all year.

In charting how earnings dispersion has evolved in Ireland in recent years we use data from nationally representative household surveys from 1987, 1994 and 1997. The 1987 and 1994 data sets have been used in earlier analyses of earnings such as Barrett, Callan and Nolan (1999a and 1999b) and descriptions of the data can be found there ${ }^{5}$. There are around 3,000 employees in each data set. Since we are focusing on individual earners rather than households, it is worth noting that validation against external sources has shown the employees in the samples to be representative in terms of age, occupational group and industrial sector.

Given appropriate data on individual earnings, there are various ways of assessing or presenting the shape of the distribution and the degree of dispersion. Most often, various percentiles of the distribution are expressed as proportions of the median. The median of the distribution is the earnings level above and below which half the earners are found. Ranking all employees by earnings from lowest to highest, the bottom decile cut-off is the earnings level below which the lowest 10 per cent of all earners fall, and the top decile the cut-off above which the highest 10 per cent are found. Correspondingly, the bottom and top quintiles are the cut-offs below/above which the bottom/top quarter of the distribution is found. A conventional approach to presenting the dispersion in earnings is then to express the bottom decile, bottom quartile, top quartile and

\footnotetext{
${ }^{5}$ The 1994 data is actually the first wave in the Irish component of the European Community Household Panel (ECHP); the 1997 data is a later wave from this panel.
} 
top decile as proportions of the median. While this gives a picture of a number of different points in the distribution, a single summary measure of dispersion may also be useful. It is also conventional to use for this purpose the ratio of the top to the bottom decile, though it is worth mentioning that different summary measures may not always lead to the same conclusions in terms of comparisons over time or across countries.

We focus first on the hourly earnings of all employees, and Table 1 shows the distribution of gross hourly earnings in the 1987, 1994 and 1997 surveys as captured by these measures. The table shows that from 1987 to 1994 there was a marked widening in dispersion at the top of the distribution. The ratio of the top decile to the median rose from 1.96 to 2.24 , while the top quartile also moved further away from the median. In the bottom half of the distribution, the bottom quartile fell away from the median but the bottom decile did not. The overall picture is thus of widening dispersion throughout the distribution except at the very bottom, with the ratio of the top to the bottom decile rising sharply from 4.2 to 4.8 .

Table 1: Distribution of Hourly Earnings in 1987, 1994 and 1997, All Employees

\begin{tabular}{lccc}
\hline as proportion of median & 1987 & 1994 & 1997 \\
\hline all employees, hourly earnings: & & & 0.48 \\
Bottom decile & 0.47 & 0.47 & 0.69 \\
Bottom quartile & 0.73 & 0.68 & 1.53 \\
Top quartile & 1.37 & 1.50 & 2.33 \\
Top decile & 1.96 & 2.24 & \\
& & & 4.81 \\
\hline Top decile/bottom decile & 4.16 & 4.77 & \\
\hline
\end{tabular}


It is particularly interesting to see whether this trend continued from 1994 to 1997, as economic growth accelerated rapidly. We see that the top decile did continue to move away from the median, reaching 2.33 by 1997 , with the top quartile also moving slightly further from the median. In the bottom half of the distribution, however, both the bottom decile and the bottom quartile now kept pace with the median, if anything increasing marginally faster. As a result, the ratio of the top to the bottom decile was essentially unchanged.

Over the whole period from 1987 to 1997 , then, there was a substantial widening in earnings dispersion in terms of hourly wages among all employees. This was more pronounced in the 1987-94 period than from 1994 on, so rapid economic growth did not lead to an acceleration in the trend. It was primarily driven by relatively rapid increases for those towards the top of the distribution, with no indication that the bottom has been falling behind the median. In the light of the relatively rapid increase in the top decile compared with the median it is of interest to look at what was happening towards the very top. The $95^{\text {th }}$ percentile (cutting of the top 5 per cent) rose even more rapidly than the $90^{\text {th }}$ percentile, going from 2.4 times the median in 1987 to 2.8 in 1994 and 3.0 in 1997 . The $99^{\text {th }}$ percentile (cutting off the top 1 per cent) went from 3.6 in 1987 to 3.8 in 1994 and 4.3 in 1997. So over the whole period top earnings rose very rapidly, but it is only at the very top that there is any suggestion that this might have accelerated from 1994 to 1997.

It is also of interest to look at the distribution of weekly gross earnings among full-time employees. Various definitions and measures of what constitutes "full-time" are used in different countries or with different datasets, depending on custom and practice and the nature of the data available. In some cases survey respondents' own categorisation of their status as full versus part-time is taken, in others different hours cut-offs are applied to 
reported hours worked. Here we base the distinction on total hours of work reported by respondents, and count as full-time those reporting at least 30 hours usual work per week, the cut-off regarded as most suitable for comparative purposes by the OECD. ${ }^{6}$ About $10 \%$ of employees worked less than this in 1987 , but by 1994 the figure was up to $15 \%$ and by 1997 it was 19\%. Table 2 shows the distribution of gross hourly and weekly earnings in 1987, 1994 and 1997 among full-time employees distinguished on this basis.

Table 2: Distribution of Weekly Earnings in 1987, 1994 and 1997, Full-time Employees

\begin{tabular}{lccc}
\hline $\begin{array}{l}\text { Weekly earnings as proportion of } \\
\text { median }\end{array}$ & 1987 & 1994 & 1997 \\
& & & \\
Bottom decile & 0.49 & 0.48 & 0.51 \\
Bottom quartile & 0.75 & 0.72 & 0.71 \\
Top quartile & 1.35 & 1.43 & 1.43 \\
Top decile & 1.82 & 1.97 & 2.02 \\
& & & \\
Top decile/bottom decile & 3.68 & 4.06 & 3.93 \\
\hline
\end{tabular}

Once again we see that from 1987 to 1994 there was a consistent widening in dispersion at the top of the distribution. The top decile as a proportion of the median rose from 1.82 to

\footnotetext{
${ }^{6}$ The recent study for the OECD by Van Baslelaer, Lemaitre and Marianna (1997) on how best to distinguish part-time from full-time employees for comparative purposes recommended that this 30 hours usual work per week be used.
} 
1.97, and the top quartile also moved further from the median. The bottom decile was just below half the median in 1987 and 1994 and just above it in 1997. The top half of the distribution showed little change between 1994 and 1997. Over the decade as a whole, then, the ratio of the top to the bottom decile increased markedly, but this was concentrated in the period from 1987 to 1994.

A comparative perspective on the Irish earnings distribution and the way it has been changing since 1987 can be obtained using measures of earnings dispersion for a range of developed countries brought together by the OECD. These figures generally refer to full-time employees and to weekly, monthly or annual rather than hourly gross earnings, so for Ireland we focus on the results for weekly earnings among full-time employees. Table 3 shows the ratio of the top to the bottom decile in 1987 and 1994 for Ireland and the other OECD countries for which figures are available for both these points in time, together with the more limited figures available for 1997. We see first that Ireland had a relatively high level of earnings inequality in 1987 compared with other OECD countries, only Canada and the USA having a higher ratio of top to bottom decile. We then see that the increase in earnings dispersion in Ireland between 1987 and 1994 was the greatest of any of the countries shown, although over the decade from 1987 the USA saw a more substantial increase in this measure. There are potentially important differences in definition and coverage across countries (including the period over which earnings are measured, how "full-time" is defined and measured, and whether all sectors are covered), so these comparisons should be treated with considerable care, but they certainly suggest that earnings dispersion in Ireland rose relatively rapidly over this period. 
Table 3: Trends in Earnings Dispersion, Ireland and other OECD Countries, 1987-1997

\begin{tabular}{|c|c|c|c|c|c|}
\hline & \multicolumn{3}{|c|}{ top decile/bottom decile } & \multicolumn{2}{|c|}{ Change } \\
\hline & 1987 & 1994 & 1997 & 1987-94 & 1987-97 \\
\hline Austria & 3.47 & 3.65 & & 0.18 & \\
\hline Australia & 2.81 & 2.86 & 2.95 & 0.05 & 0.14 \\
\hline Belgium & 2.45 & $2.24 *$ & & -0.19 & \\
\hline Canada & $4.45^{*}$ & 4.18 & & -0.27 & \\
\hline Finland & 2.51 & 2.35 & $2.33^{*}$ & -0.16 & -0.18 \\
\hline France & 3.18 & 3.08 & $3.06^{*}$ & -0.10 & -0.12 \\
\hline Germany & 2.83 & 2.80 & & -0.03 & \\
\hline Ireland & 3.68 & 4.06 & 3.93 & 0.38 & 0.25 \\
\hline Italy & 2.30 & 2.33 & $2.39 *$ & 0.03 & 0.09 \\
\hline Japan & 3.15 & 3.01 & 3.01 & -0.14 & -0.14 \\
\hline Netherlands & 2.53 & 2.58 & & 0.05 & \\
\hline New Zealand & $2.83 *$ & 3.03 & & 0.20 & \\
\hline Sweden & 2.10 & 2.18 & $2.27 *$ & 0.08 & 0.17 \\
\hline United Kingdom & 3.31 & 3.39 & 3.41 & 0.08 & 0.10 \\
\hline USA & 4.24 & 4.52 & 4.61 & 0.29 & 0.37 \\
\hline
\end{tabular}

Source: OECD Earnings Database. * Figures refer to 1986 rather than 1987, 1993 rather than 1994, 1996 rather than 1997.

To explore in more depth the way the Irish earnings distribution has evolved, we focus once again on hourly earnings and distinguish men and women, part-time versus full-time employees, and different age groups. The increase in dispersion was in fact particularly marked among men, with the top decile as a proportion of the (male) median rising from 3.5 to 5.0 over the decade. This reflects the bottom decile lagging behind the median, falling from 0.53 to 0.47 , but also the sharp increase in the top decile from 1.9 to 2.3 times the median. Although dispersion was greater among women than men employees in 1987 it rose 
by much less over the decade. With the ratio of the top to the bottom decile increasing for women from 4.4 in 1987 to 4.6 in 1997, dispersion was by then less than for men. The gap between average male and female earnings also narrowed a good deal over the decade. Where in 1987 hourly earnings for women were $82 \%$ of the corresponding average for men, by 1997 this figure had risen to $85 \%$. This represents a continuation of a longer-term trend and a range of influences is involved. For present purposes, in terms of overall earnings dispersion the continuing convergence of mean (and median) hourly earnings of men and women will have served to partially offset the increase in dispersion among women and more particularly among men.

Distinguishing part-time from full-time employees on the basis of a 30-hour per week cut-off, one finds that average hourly earnings are actually consistently higher for part-timers throughout the period. This reflects the fact that significant numbers in professional occupations, including in particular teachers, will be classed as part-timers on that basis. A comparison of median earnings for the two groups gives a rather different picture, with the median for part-timers below that for full-time employees, bringing out the different shapes of the two distributions. As already mentioned, the percentage working part-time had increased substantially over the period, from $10 \%$ in 1987 to $19 \%$ in 1997 . The part-time/fulltime distinction also sheds an interesting side-light on male versus female earnings. A much higher proportion of women than men work part-time - in the 1997 sample about one-third of full-time employees versus three-quarters of part-time employees were women. Among fulltimers, the average hourly wage for women went from $77 \%$ of the male average in 1987 to $84 \%$ in 1997. 
When employees are categorised by age, the most striking feature over the decade from 1987 is the increase in dispersion within age ranges rather than across them over the decade. Within the 25 to 34 age range, for example, the ratio of the top to the bottom decile rose from 3 to 3.6 , while within the 35 to 44 range it went from 3.7 to 4.4 . There was also some increase in variation of median earnings across the age groups, however. The median for employees aged under 25 went from $70 \%$ of the overall median in 1987 down to $66 \%$ in 1997, while the 55-64 age group saw its median rise from $116 \%$ to $126 \%$.

Bringing age and gender together, it is of interest to abstract for a moment from the impact of part-time working and focus employees on full time "adult" wages. Table 4 shows the way the distribution has evolved for full-time men aged 21 or over.

Table 4: Distribution of Hourly Earnings in 1987, 1994 and 1997, Full-Time Male

Employees Aged 21 or Over

\begin{tabular}{lccc}
\hline as proportion of median & 1987 & 1994 & 1997 \\
\hline Hourly earnings: & 0.63 & 0.55 & 0.57 \\
Bottom decile & 0.78 & 0.74 & 0.75 \\
Bottom quartile & 1.33 & 1.42 & 1.44 \\
Top quartile & 1.79 & 2.04 & 2.07 \\
Top decile & & & 3.61 \\
& & 3.68 & \\
\hline Top decile/bottom decile & 2.86 & & \\
\hline
\end{tabular}

We see that there has been a pronounced increase in dispersion among this group. The top decile has gone from 2.9 to 3.6 times the median over the decade, with most of this change 
occurring by 1994. Among full-time women aged 21 or over, by contrast, there was very little change in dispersion over the period.

\section{THE RETURNS TO EDUCATION}

In the introduction to this paper, we discussed how the increase in earnings inequality that has been observed in some countries has in turn been linked to increasing returns to skills, and in particular to education. We now explore the degree to which the trends in earnings inequality in Ireland described in the previous section are also linked to this factor. One would certainly expect the demand for educated and skilled workers to have increased in the Irish case given the pace and nature of economic growth during the 1990s. However, it is possible in the light of the rapid educational expansion in recent years that increasing demand for skills was actually met with an increased supply on a similar scale. The return to those skills could then have remained unchanged.

In order to provide a sense of the increase in the supply of skilled labour in the Irish labour market in recent years, Figure 1 shows estimates of skilled and unskilled labour supply ${ }^{7}$ over the last 25 years. Skilled labour is defined as those members of the labour force who have at least a leaving certificate (high school graduation) and unskilled as those with lower levels of educational attainment. From the early 1980s onwards the supply of unskilled labour fell quite rapidly, as a result of increasing educational participation at second level. There may also have been a "discouraged worker" effect in the 1980s due to the prolonged recession. In the 1990s the fall in supply of unskilled labour has continued, albeit more slowly. It has been

\footnotetext{
${ }^{7}$ Here total labour supply is defined as the labour force as estimated by the Central Statistics Office for each year. The data used in the graph up to 1987 are obtained from successive censuses by interpolation. From 1988 onwards the numbers are taken from an analysis of the Labour Force Survey micro data.
} 
modified in recent years by rising labour force participation among women with limited educational attainment.

Over the whole period from 1971 to 1997 the supply of skilled labour has risen rapidly and fairly continuously. The one exception was the late 1980 s, when emigration, predominantly of skilled people peaked. Between 1971 and 1981 supply of skilled labour rose by 95 per cent, between 1981 and 1991 it rose by over 72 per cent and between 1991 and 1997 there was a further increase of 35 per cent. In the 1990s immigration and rising female labour force participation have contributed to the increase in skilled labour.

Figure 1 Labour Supply by Educational Attainment

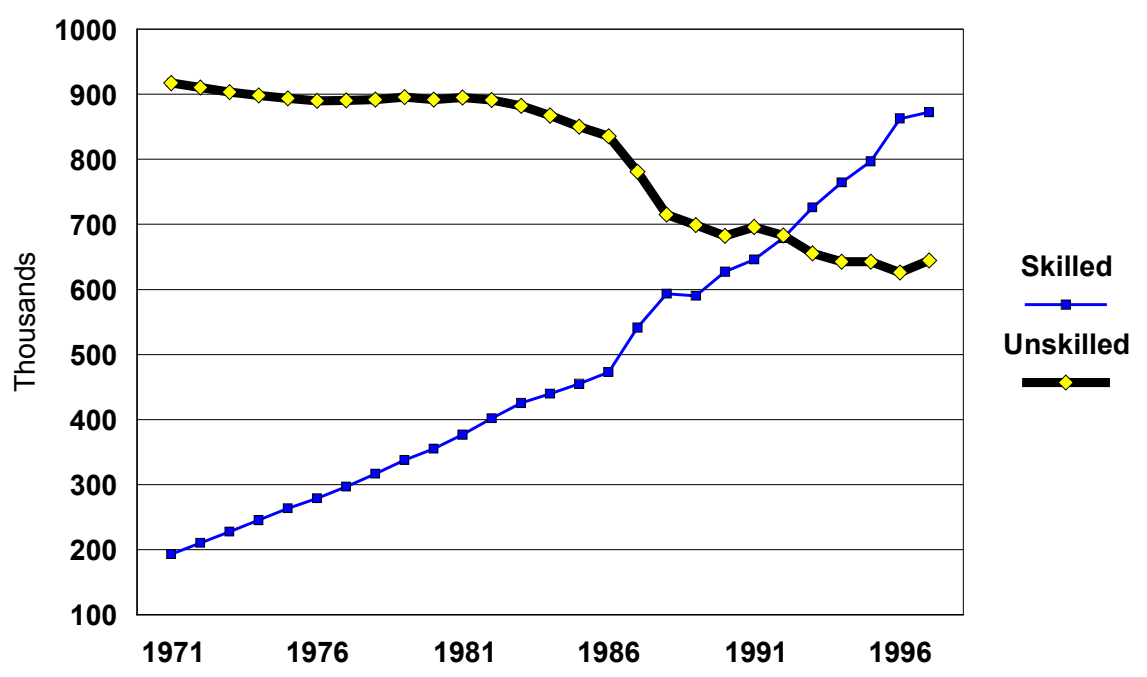

As regards labour demand, rising demand for skilled labour occurred throughout the industrialised economies (Nickell and Bell, 1995) over the 1980s and the 1990s. However, the shift in demand in Ireland has been accentuated by the impact of foreign direct investment on the economy. The bulk of the foreign direct investment has, until recently, gone to the 
manufacturing sector. By 1997 almost 50 per cent of all employment in manufacturing was in foreign owned firms and a quarter of all employment was in US owned firms (Table 5). The bulk of this employment in foreign owned firms was in the high-technology sector, broadly defined.

Table 5: Share of total manufacturing employment by sector and by ownership

\begin{tabular}{lcccc}
\hline \multicolumn{3}{c}{ Irish Owned Foreign Owned } & Total \\
\hline & & \multicolumn{3}{c}{ Of which: US } \\
Owned \\
Other & 40.1 & 17.3 & 7.1 & 57.4 \\
High Tech. & 12.1 & 30.5 & 18.2 & 42.6 \\
Total & 52.2 & 47.8 & 25.2 & 100.0 \\
\hline
\end{tabular}

In the 1960s the two sectors of the economy that employed the bulk of the skilled labour force were financial and professional services. They still are the major employers of skilled labour, but the gap in levels of human capital employed in these sectors and in the rest of the economy has narrowed considerably, with a general upgrading of the skill levels in hightechnology manufacturing (engineering, including computers, and chemicals). The high technology manufacturing sector, driven by the inflow of foreign firms, now has an above average level of human capital in its labour force. The most rapid increase in the demand for skilled labour in the 1990s has occurred in the high technology manufacturing and in financial services, both of which are affected by the inflow of new firms from abroad.

We now turn to our estimation of the relative impacts of increasing labour supply and labour demand on the returns to education. We estimate earnings functions and examine the return to different levels of educational attainment in the years 1987, 1994 and 1997, once again drawing on the household survey data sets. Before presenting our estimates of the returns to 
education, we will briefly discuss the method used. We estimate regression equations in which the dependent variable is the logarithm of hourly earnings. We include as independent variables a range of factors that influence earnings, including education. While this type of earnings equation is used extensively in analyses of this sort, there is not general agreement on what dependent variables to include. For this reason, we estimate a range of specifications and present the results of each. It will be seen that while the coefficients on the educational categories vary across specifications, a general picture emerges which sheds additional light on the findings of the previous section.

In order to enter education in the regressions as a categorical variable, we set up a number of education categories based on the highest level of schooling attained. These are as follows:

"Primary only": This includes those who left school at the end of primary level, or did some second-level schooling but obtained no qualification.

Junior cycle: This includes the Group and Intermediate Certificates, as well as their recent replacement, the Junior Certificate. These are exams taken at the midway stage of second level education.

Leaving Certificate: This is the qualification obtained by those successfully completing the senior cycle of second-level education, plus a small number with qualifications under the Post Leaving Certificate and Vocational Preparation and Training Programmes.

Diploma or other third-level: This includes non-degree qualifications from such institutions as regional technical colleges.

University degree: This includes both primary and higher degrees. 
In each of the regressions, "primary" is the omitted category and so the returns to each level of education is measured relative to that group.

We estimate five specifications of the wage equation for each of the three years. The variables included are as follows:

Specification 1: Age and its square, the educational categories, and sex interacted with marital status (married man, married woman and single woman, the omitted category being single men);

Specification 2: As specification 1, but with the educational categories interacted with age bands (15-32, 33-49, and 50-64);

Specification 3: $\quad$ Years worked and its square, years spent in training or further education after first leaving the full-time education system, years not worked and its square, ${ }^{8}$ the educational attainment categories, and the sex/marital status dummies;

Specification 4: As specification 3, but with occupation- and industry-specific unemployment rates (obtained on a 1 digit basis from the large-scale Labour Force Survey conducted by the Irish Central Statistics Office) added to the control variables;

Specification 5: As specification 4, but with interaction terms for the levels of education and three age bands (15-32, 33-49, and 50-64).

The choice of these five specifications is designed to address three main issues. First, what is the impact of the inclusion of measures of actual experience on the education coefficients?

\footnotetext{
${ }^{8}$ This specification seeks to capture the effects of experience more adequately than via simply age, by including a measure of years since first leaving full-time education broken down into years spent in work, years spent in training or back in full-time education, and years spent out of work.
} 
Many studies do not have access to such data and are forced to rely instead on potential experience as measured by age or age since leaving school. Comparisons based on specifications (1) and (3) and (2) and (5) can help to address this issue. Second, how are (changes in) the returns to education affected by allowing for possible time-related differences in returns; there are many reasons why the premia commanded by particular levels of educational qualification may vary for younger and older age groups. The specifications interacting education levels and age-bands allow for some such variation, whereas the more common practice of assuming a single premium attaching to the educational level across all age groups does not. Comparisons based on specifications (1) and (2), and (3) and (5) can help to address this issue. Third, the impact of the inclusion of measures of the industry- and occupation-specific unemployment rates in the wage equation can be examined by comparing specifications (3) and (4). Identical specifications were used for the 1987, 1994 and 1997 analyses $^{9}$.

In Table 6, we present the estimates of the returns to education from Specification 1, 3 and 4 for the three years. As would be expected, the returns relative to the contrast category rise with level of education. For example, from Specification (1) in 1987 we can read that those with junior cycle qualifications earned 17 percent more per hour than those with only primary schooling; those with leaving certificates earner 37 percent more and those with degrees earned 86 percent more.

\footnotetext{
${ }^{9}$ The earnings equations are estimated including both men and women. When estimating such equations for women, selection correction techniques are often employed, to account for women who do not work and so for
} 
Turning to the comparison of these returns over time, we will firstly look at the change between 1987 and 1994. While there is some movement in the point estimates between 1987 and 1994, the only differences that are statistically significant are those for university degrees. All three specifications show the returns to the highest education increasing. This finding is consistent with the increase in earnings inequality between 1987 and 1994, documented above. It suggests that in spite of increased numbers of skilled employees and centralised wage bargaining, the increase in the demand for skilled labour was sufficiently strong for the price of that labour to be bid up.

If we compare the returns to education in 1994 and 1997, a slightly more mixed picture emerges. According to Specifications (1) and (3), the returns to university education in 1997 were statistically the same as in 1994. However, Specification (4) indicates that the return actually fell. As this specification includes measures of unemployment in occupations and industries, and as these numbers changed substantially between 1994 and 1997, the change in the point estimate may reflect interactions in the effects of education and unemployment on earnings. A conservative summary of the results between 1994 and 1997 would be to say that the increase in returns to university education that was observed between 1987 and 1994 did not continue between 1994 and 1997. Again, this is consistent with the reduction in the growth of earnings inequality between 1994 and 1997.

whom no wage is reported. As the equations with men only showed a similar pattern to those presented here, we opted for the simpler approach. 
Table 6: Estimates of Returns to Education: 1987, 1994 and 1997

\begin{tabular}{|c|c|c|c|c|}
\hline \multirow[b]{2}{*}{$\begin{array}{l}\text { Wage } \\
\text { equation } \\
\text { specification }\end{array}$} & \multirow[b]{2}{*}{$\begin{array}{l}\text { Highest educational } \\
\text { qualification }\end{array}$} & \multicolumn{2}{|c|}{ All Employees } & \multirow[b]{2}{*}{$\begin{array}{l}1997 \\
\text { coefficients } \\
\text { (standard } \\
\text { errors) }\end{array}$} \\
\hline & & $\begin{array}{l}1987 \\
\text { coefficients } \\
\text { (standard } \\
\text { errors) }\end{array}$ & $\begin{array}{l}1994 \\
\text { coefficients } \\
\text { (standard } \\
\text { errors) }\end{array}$ & \\
\hline \multirow[t]{4}{*}{ (1) } & $\begin{array}{l}\text { Group, Inter., Junior } \\
\text { Cert. }\end{array}$ & $0.17(0.03)$ & $0.22(0.03)$ & $0.20(0.03)$ \\
\hline & Leaving Certificate & $0.37(0.03)$ & $0.41(0.03)$ & $0.43(0.03)$ \\
\hline & $\begin{array}{l}\text { Diploma or other } 3 \text { rd } \\
\text { level }\end{array}$ & $0.58(0.04)$ & $0.54(0.03)$ & $0.61(0.04)$ \\
\hline & University degree & $0.86(0.04)$ & $1.01(0.03)^{*}$ & $1.02(0.03)$ \\
\hline \multirow[t]{4}{*}{ (3) } & $\begin{array}{l}\text { Group, Inter., Junior } \\
\text { Cert. }\end{array}$ & $0.12(0.03)$ & $0.18(0.03)$ & $0.15(0.03)$ \\
\hline & Leaving Certificate & $0.36(0.03)$ & $0.36(0.03)$ & $0.33(0.03)$ \\
\hline & $\begin{array}{l}\text { Diploma or other 3rd } \\
\text { level }\end{array}$ & $0.59(0.04)$ & $0.53(0.03)$ & $0.56(0.04)$ \\
\hline & University degree & $0.88(0.04)$ & $1.01(0.03)^{*}$ & $0.95(0.04)$ \\
\hline \multirow[t]{4}{*}{ (4) } & $\begin{array}{l}\text { Group, Inter., Junior } \\
\text { Cert. }\end{array}$ & $0.11(0.03)$ & $0.17(0.03)$ & $0.12(0.03)$ \\
\hline & Leaving Certificate & $0.34(0.03)$ & $0.34(0.03)$ & $0.27(0.03)$ \\
\hline & $\begin{array}{l}\text { Diploma or other 3rd } \\
\text { level }\end{array}$ & $0.56(0.04)$ & $0.51(0.03)$ & $0.48(0.04)$ \\
\hline & University degree & $0.85(0.04)$ & $0.98(0.03)^{*}$ & $0.85(0.04)^{*}$ \\
\hline
\end{tabular}

Note: * indicates an estimate that is statistically different from the corresponding estimate in the earlier year.

In Table 7, we present the estimates of education returns by age categories. The point estimates are now based on smaller cell sizes and so the standard errors are correspondingly larger. For this reason, it is less likely that we will observe differences that are statistically significant. We can still consider the pattern of coefficients and draw conclusions, even though they are on a weaker statistically footing. 
We now see that for the youngest age group, the returns to university education were either identical or increased slightly between 1987 and 1994, at least in terms of point estimates. The increases in these returns in Table 6 are now seen to have been concentrated on the middle or older age groups. For the middle-aged group, the increase is statistically significant in Specification (5); it is also relatively large in Specification (2). For the older group, the differences in the point estimates are also relatively large.

This different trend in returns to university education across age groups between 1987 and 1994 calls for an explanation. One possible explanation is based on the notion that the skilled labour market is not homogeneous but rather is differentiated by experience levels. By this we mean that inexperienced skilled workers are not perfect substitutes for experienced skilled workers. As the increase in supply of educated workers would have been made up of those leaving the education system, they would have been primarily in the younger age category. If the skilled labour market is indeed differentiated between the newly-skilled and the more experienced skilled employees, the increase in supply of newly-skilled employees would not have an impact in the market of experienced skilled workers. Hence the increase in demand for skills was met with a supply increase in one part of the skilled market and so the price did not rise; in the other part of the market, i.e. the experienced skilled market, no supply increase was forthcoming and so prices did rise. 
Table 7: Estimates of Returns to Education by Age Category: 1987, 1994 and 1997

\begin{tabular}{|c|c|c|c|c|}
\hline \multirow{3}{*}{$\begin{array}{l}\text { Wage } \\
\text { equation } \\
\text { specification } \\
\text { (2) }\end{array}$} & \multirow[b]{2}{*}{$\begin{array}{l}\text { Highest educational } \\
\text { qualification }\end{array}$} & \multicolumn{3}{|c|}{ All Employees } \\
\hline & & $\begin{array}{c}1987 \\
\text { coefficients }\end{array}$ & $\begin{array}{c}1994 \\
\text { coefficients }\end{array}$ & $\begin{array}{c}1997 \\
\text { coefficients }\end{array}$ \\
\hline & Age group 15-32 & & & \\
\hline & Group, Inter., Junior Cert. & 0.08 & 0.11 & $0.23(0.05)$ \\
\hline & Leaving Certificate & 0.23 & 0.21 & $0.38(0.04)^{*}$ \\
\hline & Diploma or other 3rd level & 0.39 & 0.26 & $0.53(0.06)^{*}$ \\
\hline & University degree & 0.73 & 0.73 & $0.85(0.06)$ \\
\hline & Age group 33-49 & & & \\
\hline & Group, Inter., Junior Cert. & 0.18 & 0.24 & $0.14(0.04)$ \\
\hline & Leaving Certificate & 0.42 & 0.52 & $0.42(0.04)$ \\
\hline & Diploma or other 3rd level & 0.56 & 0.67 & $0.66(0.05)$ \\
\hline & University degree & 0.90 & 1.13 & $1.10(0.05)$ \\
\hline & Age group 50-64 & & & \\
\hline & Group, Inter., Junior Cert. & 0.21 & 0.14 & $0.13(0.06)$ \\
\hline & Leaving Certificate & 0.49 & 0.35 & $0.52(0.06)^{*}$ \\
\hline & Diploma or other 3rd level & 0.87 & 0.71 & $0.65(0.09)$ \\
\hline & University degree & 0.94 & 1.04 & $1.06(0.06)$ \\
\hline \multirow[t]{15}{*}{$(5)$} & Age group 15-32 & & & \\
\hline & Group, Inter., Junior Cert. & 0.05 & 0.14 & $0.13(0.05)$ \\
\hline & Leaving Certificate & 0.26 & 0.26 & $0.21(0.05)$ \\
\hline & Diploma or other 3rd level & 0.46 & 0.39 & $0.40(0.06)$ \\
\hline & University degree & 0.86 & 0.91 & $0.74(0.06)^{*}$ \\
\hline & Age group 33-49 & & & \\
\hline & Group, Inter., Junior Cert. & 0.12 & 0.18 & $0.11(0.04)$ \\
\hline & Leaving Certificate & 0.38 & 0.42 & $0.29(0.04)$ \\
\hline & Diploma or other 3rd level & 0.54 & 0.60 & $0.52(0.05)$ \\
\hline & University degree & 0.88 & $1.06^{*}$ & $0.91(0.05)^{*}$ \\
\hline & Age group 50-64 & & & \\
\hline & Group, Inter., Junior Cert. & 0.16 & 0.13 & $0.06(0.05)$ \\
\hline & Leaving Certificate & 0.45 & 0.34 & $0.38(0.05)$ \\
\hline & Diploma or other 3rd level & 0.79 & 0.63 & $0.49(0.08)$ \\
\hline & University degree & 0.78 & 0.95 & $0.83(0.06)$ \\
\hline
\end{tabular}

Comparing the return to education between 1994 and 1997, and again focussing on the returns to university education, we can see that the returns appear to have either stayed the same as 1994, or to have fallen, for all age groups. Either way, it can be said that no age group continued to enjoy increases in return between 1994 and 1997. Specification (2) does 
show a rise in the returns for the youngest age group but this is not statistically significant and under Specification (5), a statistically significant fall is observed. Once again, an explanation is required especially as it might have been assumed that increased economic growth would have led to further increases in the return to university education.

Above we suggested that the relative stability of the return for the youngest age group between 1987 and 1994 was the result of an increased supply of younger skilled workers and this argument can be advanced here also to explain the fall for younger workers. However, we need to look elsewhere for an explanation of the decline in the return for older workers, especially the middle-aged group for whom a statistically significant fall in observed.

We draw on another supply explanation. The growth in the economy in recent years has brought with it the return to Ireland of former emigrants and the entry of immigrants. Two characteristics of the inflow are relevant to our findings. First, although there was a net inflow of 16,400 between 1994 and 1997, this aggregate figure hides large differences across age groups. For those aged 15-25, there was a net outflow of 44,100; for those aged 25-44, there was a net inflow of $27,400^{10}$, which is about 3 percent of the population of that age. The second relevant characteristic of the inflow relates to its educational composition. Barrett and Trace (1998) have shown that both returning migrants and immigrants in the years 1994 to 1996 had higher levels of educational attainment than the domestic population. For example, while 12.7 percent of the domestic labour force aged 30 to 39 had university degrees, 28 percent of returning migrants in that age group had degrees. The corresponding figure for immigrants was 43.2 percent. Hence, the inflow of skilled workers in this middle age group

\footnotetext{
${ }^{10}$ All figures are derived from a Central Statistics Office (1999) release on migration statistics.
} 
would be substantially higher as a percentage of the corresponding age/education population than the 3 percent mentioned above. This may explain the possible fall or stability in the return to university education for this group over that period.

\section{TESTING THE IMMIGRATION HYPOTHESIS}

We test this immigration hypothesis following an approach used by Borjas, Freeman and Katz (1997). While many studies have looked at the labour market impact of immigration by relating changes in wages to inflows of migrants across regions, Borjas et al have criticised this approach. They argue that adjustments to immigration may take the form of native workers not moving to areas that have experienced large inflows of immigrants. If this does occur, immigrants may have effects on the national labour market that are not observed in inter-regional comparisons. For this reason, Borjas et al simulate the impact of immigrants on wages in a national framework. They do so by comparing the nation's supplies of skilled and unskilled labour under different immigration levels and then assessing the relative wage impacts.

Broadly following this approach, we develop a simple model of the Irish labour market that allows us to compare outcomes with and without an inflow of skilled immigrants. The model is based on a theoretical structure, the parameters of which are then estimated using data from 1971 to 1996.

The structure of the model can be found in the Appendix so here we provide only the essential features. The model consists of two kinds of labour - skilled and unskilled. Within the model, the wages of the skilled and employment levels of both the skilled and unskilled 
are determined, along with output ${ }^{11}$. Among the specific features are the following. While the supply of unskilled labour is assumed to be inelastic, the elasticity of supply of skilled labour is assumed to be greater. This reflects the fact that the skilled elasticity has been unusually high because of the ready movement of skilled labour in and out of the country and because of the elasticity of supply of skilled female labour. The elasticity of substitution between skilled and unskilled labour in Ireland has been found to be relatively low (Kearney, 1999) and this is incorporated into the model by assuming that the elasticity of substitution is zero. Regarding output, an equation is used to reflect the fact that Irish output is quite sensitive to the relative cost (or profitability) of producing in Ireland compared to other countries (Bradley and Fitz Gerald, 1988 and Bradley, Fitz Gerald and Kearney, 1993). At the level of the Irish economy skilled and unskilled labour are assumed to be complements - a rise in the cost of either factor will reduce Irish output and employment of both kinds of labour. Because of the assumed zero elasticity of substitution between the two kinds of labour within the economy the output (or scale) effect dominates any substitution effect (Bradley, Fitz Gerald and Kearney, 1993).

Within this model the effect of immigration of skilled labour is to reduce upward pressure on the skilled wage rate. In turn, this reduces the cost of producing in Ireland and increases output. Because Irish skilled and unskilled labour are complements, the increase in competitiveness due to falling skilled wage rates also increases the demand for unskilled labour. Thus the effect of skilled migration is to reduce the pressures for growing inequality in wage rates through reducing skilled wage rates and tightening the market for unskilled labour.

\footnotetext{
${ }^{11}$ The wages of the unskilled are assumed to be a fixed mark-up on social welfare payments.
} 
Over the four years 1996 to 1999 net immigration averaged 16,000 a year. As Barrett and Trace (1998) have shown, the bulk of these people, whether they were returning emigrants or foreigners, had a high level of education. As a result, they significantly increased the supply of skilled labour over that period. Applying an increase in skilled labour of this magnitude to the labour market model described above allows us to estimate the impact of immigration into Ireland ${ }^{12}$.

The estimates of the effects are presented in Table 8 . Four years after the shock, the impact of the immigration was to increase the supply of skilled labour by 3.2 per cent and to reduce skilled wage rates by 4.7 percentage points. (The model assumes that due to high levels of unskilled unemployment unskilled wage rates are unaffected by demand.) ${ }^{13}$ As a result, the model would suggest that the impact of net immigration of skilled labour was to narrow the gap between skilled and unskilled wage rates by around 4.5 percentage points compared to the situation with no net migration.

This relaxation in the skilled labour supply constraint, and the resulting reduction in skilled wage rates, made Ireland more competitive on world markets. The model would suggest that this raised the level of GNP in the short run by 1.5 percentage points. The long run impact would be substantially greater, due to the slow adjustment of productive capacity to changing economic circumstances. Ultimately the model would suggest that the impact of the

\footnotetext{
${ }^{12}$ As there were 1.5 million in Ireland's labour force in 1996, the increase of 64,000 is 4.3 percent.

${ }^{13}$ However, recent evidence suggests that this may no longer be the case and that the tightening of the unskilled labour market is exerting upward pressure on wage rates.
} 
improved competitiveness would be to raise the level of GNP by around 4 percentage points. With rapid adjustment of both skilled and unskilled employment (they are complements) to the changed circumstances, the unemployment rate is estimated to have fallen by around 0.7 percentage points, all of which is concentrated among those members of the labour force with limited education.

Table 8: Effects of Net Migration in the Four Years Ended 1999

\begin{tabular}{llc}
\hline Skilled $\quad$ Labour & $\%$ & 3.2 \\
Supply & & \\
\hline Skilled Wage Rates & $\%$ & -4.7 \\
GNP & $\%$ & 1.5 \\
Total Employment & $\%$ & 3.2 \\
Unemployment rate & $\begin{array}{l}\text { Percentage } \\
\text { points }\end{array}$ & -0.7 \\
& \\
\hline
\end{tabular}

Of course this analysis is only partial in nature as it does not take account of the wider impact of higher growth in putting increased pressure on existing infrastructure, in particular on housing. The model also incorporates some simplifying assumptions that are probably inappropriate under current circumstances. While the model assumption that unskilled wage rates are unaffected by labour market pressures was reasonably appropriate in the 1980s and early 1990s, it is clearly unrealistic under current circumstances. To the extent that the tightening of the unskilled labour market impacts on unskilled wage rates, the narrowing in wage dispersion arising from immigration will be even greater than shown in Table 8 .

\section{CONCLUSIONS}

Increasing earnings dispersion and rising returns to education and skill have received a great deal of attention internationally, and the aim of this chapter has been to document what has been happening in Ireland in this regard. We saw that over the period from 1987 to 1997 
there was a substantial widening in earnings dispersion in terms of hourly wages among all employees. This was more pronounced in the 1987-94 period than from 1994 on, so rapid economic growth did not lead to an acceleration in the trend. It was primarily driven by relatively rapid increases for those towards the top of the distribution, with no indication that the bottom has been falling behind the median. Ireland already had a relatively high level of earnings inequality in 1987 compared with other OECD countries, and the increase in earnings dispersion was also relatively rapid.

From the early 1970s the supply of skilled labour in Ireland has risen rapidly as a consequence of educational expansion, with immigration becoming an important factor in the 1990s. The supply of unskilled labour, on the other hand, fell quite rapidly from the early 1980s as a result of increasing educational participation at second level. As regards labour demand, rising demand for skilled labour occurred throughout the industrialised economies over the 1980s and the 1990s; in Ireland, this has been accentuated by the scale of foreign direct investment in the high-technology sector. To tease out the relative impacts of increasing labour supply and labour demand on the returns to education, we estimated earnings functions and examined the return to different levels of educational attainment for 1987, 1994 and 1997. The results suggested an increase in returns to third-level education between 1987 and 1994, but this was confined to the middle or older age groups and did not continue from 1994 to 1997 - indeed declining returns for the middle age ranges were then seen.

Immigration of skilled and experienced workers - particularly returning migrants - became substantial in the mid 1990s and this may explain the stability or even decline in the return to university education for this group over that period. Such an immigration effect on the 
differential between skilled and unskilled wages was consistent with the results from a simple model of the Irish labour market, with parameters estimated using data from 1971 to 1996, that allowed outcomes with and without an inflow of skilled immigrants to be compared. So while immigration into the United States may have been a source for increased earnings inequality, the evidence presented here suggests that the opposite was true in Ireland. 


\section{REFERENCES}

Barrett, A., Callan, T. and Nolan, B. (1999a). "Rising Wage Inequality, Returns to Education and Labour Market Institutions: Evidence from Ireland", British Journal of Industrial Relations, 37 (1), 77-100.

Barrett, A., Callan, T. and Nolan, B. (1999b). "Returns to Education in the Irish Youth Labour Market", Journal of Population Economics, 12, 313-326.

Barrett, A. and Trace, F. (1998). "Who is Coming Back? The Educational Profile of Returning Migrants in the 1990s", Irish Banking Review, Summer.

Blau, F. and Kahn, L. (1996). "International Differences in Male Wage Inequality: Institutions Versus Market Forces”, Journal of Political Economy, 104 (4), 791-837.

Borjas, G., Freeman, R. and Katz, L. (1997). "How Much Do Immigration and Trade Affect Labour Market Outcomes?", Brookings Papers on Economic Activity, 1, 1-67.

Borjas, G. and Ramey, V. (1994). "Time-Series Evidence on the Sources of Trends in Wage Inequality", American Economic Review, Papers and Proceedings, 84, 10-16.

Bound, J. and Johnson, G. (1992). "Changes in the Structure of Wages During the 1980s: An Evaluation of Alternative Explanations", American Economic Review, 82, 371-92.

Bradley, J. and Fitz Gerald, J. (1998). "Industrial Output and Factor Input Determination in an Econometric Model of a Small Open Economy"'” European Economic Review, 32, 122741.

Bradley, J., J. Fitz Gerald and I. Kearney, 1993. "Modelling Supply in an Open Economy Using a Restricted Cost Function”, Economic Modelling, Volume 10, No. 1, January, pp. $11-21$.

Burtless, G. (1995). "International Trade and the Rise in Earnings Inequality", Journal of Economic Literature, 33(2), 800-816. 
Central Statistics Office (1999). Population and Migration Estimates, Cork: Central Statistics Office.

DiNardo, J., Fortin, N. and Lemieux, T. (1996). "Labor Market Institutions and the Distribution of Wages, 1973-1992: A Semiparametric Approach”, Econometrica, 64 (5), 1001-44.

DiNardo, J. and Lemieux, T. (1997). "Diverging Male Wage Inequality in the United States and Canada, 1981-1988: Do Institutions Explain the Difference?”, Industrial and Labor Relations Review, 50 (4), 629-651.

Freeman, R. (1993). "How Much Has De-unionization Contributed to the Rise in Male Earnings Inequality?", in Danziger, S. and Gottschalk, P. (eds.), Uneven Tides: Rising Inequality in America, New York: Russell Sage Foundation.

Gosling, A. and Machin, S. (1995). "Trade Unions and the Dispersion of Earnings in British Establishments", Oxford Bulletin of Economics and Statistics, 57, 167-84.

Gosling, A., Machin, S. and Meghir, C. (1994). "What Has Happened to Men's Wages Since the Mid-1960s?", Fiscal Studies, 15 (4), 63-87.

Gottschalk, P. and Joyce, M. (1997). "Cross-National Differences in the Rise in Earnings Inequality:Market and Institutional Factors", LIS Working Paper No. 160, Luxembourg: CEPS/INSTEAD.

Juhn, C., Murphy, K. and Pierce, B. (1992). "Wage Inequality and the Rise in Returns to Skill”, Journal of Political Economy, 101(3), 410-42.

Katz, L. and Murphy, K. (1992). “Changes in Relative Wages, 1963-1987: Supply and Demand Factors", Quarterly Journal of Economics, 107(1), 35-78.

Kearney, I. (1998). "Estimating the Demand for Skilled Labour, Unskilled Labour and Clerical Workers: A Dynamic Framework”, ESRI Working Paper No. 91.

Leslie, D. and Pu, Y. (1996). "What Caused Rising Wage Inequality in Britain? Evidence from Time Series 1970-93”, British Journal of Industrial Relations, 34, 111-30. 
Levy, F. and Murnane, R. (1992). "US Earnings Levels and Earnings Inequality: A Review of Recent Tremds and Proposed Explanations ”, Journal of Economic Literature, 30(3), 1333-81. Machin, S. (1997). "The Decline of Labour Market Institutions and the Rise in Wage Inequality in Britain", European Economic Review, 41, 647-57.

Nickell, S. and Bell, B. (1995). "The Collapse in Demand for the Unskilled and Unemployment Across the OECD”, Oxford Review of Economic Policy, 11(1), 40-62.

OECD (1993). Employment Outlook, Paris: OECD.

OECD (1996). Employment Outlook, Paris: OECD.

Schmitt, J. (1995). “The Changing Structure of Male Earnings in Britain, 1974-88”, in Freeman, R. and Katz, L. (eds.), Differences and Changes in Wage Structures, Chicago: University of Chicago Press.

Van Baselaer, A., Lemaitre, G. and P. Marianna, P. (1997). The Definition of Part-time Work for the Purpose of International Comparisons, Labour Market and Social Policy Occasional Papers No. 22, Paris: OECD.

Wood, A., (1994). North-South Trade, Employment and Inequality: Changing Fortunes in a Skill-driven World, Oxford: Clarendon Press. 


\section{APPENDIX}

Labour Market Model

Equations determining labour force participation rates:

$N_{h} / P O P_{h}=f\left(w_{h}, p_{c}, z_{h}\right)$

$N_{l} / P O P_{l}=f\left(w_{l}, p_{c}, r, z_{l}\right)$

The first equation determines $\mathrm{w}_{\mathrm{h}}$

The second equation determines $\mathrm{N}_{1}$

The unskilled wage rate:

$w_{l}=\gamma r$

This determines $\mathrm{w}_{1}$. Post 1980 until the late 1990s it is driven

by the rate of social welfare (replacement rate) r. For the 1970 s

and for recent years an alternative formulation is needed.

Immigration:

$M_{h}=f\left(w_{h}, w^{u}, U R, U R^{u}\right) \quad$ This equation determines $\mathrm{M}_{\mathrm{h}}$.

$M_{l}=0 \quad$ Post 1980: $M_{l}=0$.

Irish Output is a function of world output and competitiveness (vis a vis the UK).

$Q^{i}=f\left(Q^{w}, w^{i}, w^{u}, \operatorname{tax}^{i}, \operatorname{tax}^{u}\right.$, time $) \quad$ This equation determines GNP

The weighted average wage rate for Ireland:

$w^{i}=\alpha w_{h}+(1-\alpha) w_{l} \quad$ This equation determines $\mathrm{w}^{\mathrm{i}}$

The labour demand equation for the composite labour input L: 
$L=f\left(Q^{i}, \frac{w}{p_{c}}\right.$, time $) \quad$ This equation determines $\mathrm{L}$

The shares of skilled and unskilled labour in the labour bundle of inputs is purely a function of technical progress (time). It is assumed that there is zero elasticity of substitution between the two types of labour (see Kearney, 1998)

$\frac{L_{h}}{L_{l}}=f($ time $) \quad$ This equation determines $\mathrm{L}_{\mathrm{h}}$

Total employment:

$L=L_{h}+L_{l} \quad$ This equation determines $\mathrm{L}_{1}$

Skilled labour is assumed to be fully employed - frictional unemployment is defined by $\beta$

$\frac{L_{h}}{N_{h}}=\beta \quad$ This equation determines $\mathrm{N}_{\mathrm{h}}$. Full employment is defined by $\beta$.

The labour force:

$N=N_{h}+N_{l} \quad$ This equation determines N.

The unemployment rate:

$U R=(N-L) / N * 100 \quad$ This equation determines the unemployment rate UR

Population:

Pop $=\mathrm{Pop}_{h}+\mathrm{Pop}_{l} \quad$ This equation determines POP.

Pop $_{h}=$ DelPOP $_{h}+M_{h} \quad$ This equation determines skilled population aged 20-64

Pop $_{l}=$ DelPOP $_{l}+M_{l} \quad$ This equation determines the unskilled population aged 20-64 
Where:

$\mathrm{N}_{\mathrm{h}} \quad=\quad$ Labour supply - skilled

$\mathrm{N}_{1}=$ Labour supply - unskilled

$\mathrm{w}_{\mathrm{h}}=\quad$ Wage rate - skilled

$\mathrm{w}_{\mathrm{l}}=$ Wage rate - unskilled

$\mathrm{w}^{\mathrm{u}} \quad=\quad$ Wage rate $-\mathrm{UK}$

$\mathrm{p}_{\mathrm{c}} \quad=\quad$ Consumer prices

$\mathrm{r} \quad=\quad$ rate of social welfare

$\mathrm{Q}^{\mathrm{i}}=$ Irish Output

$\mathrm{Q}^{\mathrm{W}}=$ World Output

$\mathrm{w}^{\mathrm{i}}=\quad$ Average wage rate in Ireland

$\mathrm{L}_{\mathrm{h}} \quad=\quad$ Employment - skilled

$\mathrm{L}_{1}=$ Employment - unskilled

$\mathrm{L}=$ Total employment

$\mathrm{M}_{\mathrm{h}}=$ Immigration, skilled

$\mathrm{M}_{1}=$ Immigration, unskilled

$\mathrm{N} \quad=\quad$ Labour supply

$\mathrm{UR}=$ unemployment rate

$\mathrm{UR}^{\mathrm{u}}=$ unemployment $-\mathrm{UK}$

$\operatorname{tax}^{\mathrm{i}}=\quad$ Tax wedge in Ireland

$\operatorname{tax}^{\mathrm{u}}=$ Tax wedge in UK

DelPOP $_{\mathrm{h}}=\quad$ Natural increase in skilled population aged 20-64.

DelPOP $_{1}=\quad$ Natural increase in unskilled population aged 20-64. 


\section{IZA Discussion Papers}

No. Author(s)

71

72

L. Goerke

J. Fersterer

R. Winter-Ebmer

73

G. S. Epstein

S. Nitzan

74 M. Kräkel

75

B. Henry

M. Karanassou

D. J. Snower

76

G. Brunello

M. Giannini

77

C. M. Schmidt

78

J. Hansen

R. Wahlberg

79

J. S. Earle

Z. Sakova

80 J. C. van Ours

J. Veenman

81

T. J. Hatton

S. Wheatley Price

82 K. A. Konrad

83

R. Euwals

84

C. M. Schmidt

85 S. Pudney

M. A. Shields

86

J.P. Haisken-DeNew

C. M. Schmidt

87
Title

Area

Date

The Wedge

3

$11 / 99$

Are Austrian Returns to Education Falling Over

Time?

The Endogenous Determination of Minimum Wage 3

Strategic Mismatches in Competing Teams

5

Adjustment Dynamics and the Natural Rate: An 1

Account of UK Unemployment

Selective Schools

5

Knowing What Works: The Case for Rigorous

Program Evaluation

Endogenous Schooling and the Distribution of the Gender Wage Gap

Entrepreneurship from Scratch: Lessons on the Entry Decision into Self-Employment from Transition Economies

The Netherlands: Old Emigrants - Young Immigrant Country

Migration, Migrants and Policy in the United Kingdom

Privacy, time consistent optimal labor income taxation and education policy

Female Labour Supply, Flexibility of Working Hours, 1 and Job Mobility in the Netherlands

The Heterogeneity and Cyclical Sensitivity of 1 Unemployment: An Exploration of German Labor Market Flows

Gender and Racial Discrimination in Pay and 5/6 Promotion for NHS Nurses

Money for Nothing and Your Chips for Free?

5 The Anatomy of the PC Wage Differential

Educational Mismatch and Wages in Germany
5

$11 / 99$

$11 / 99$

$12 / 99$

$12 / 99$

$12 / 99$

$12 / 99$

$12 / 99$

$12 / 99$

$12 / 99$

$12 / 99$

$12 / 99$

$12 / 99$

12/99

$12 / 99$

$12 / 99$

$12 / 99$ 
P. Cahuc

A. Zylberberg

97

A. Barrett

98

J.P. Haisken-DeNew

C. M. Schmidt

L. Husted

H. S. Nielsen

M. Rosholm

N. Smith
G. Brunello
C. Graziano
B. Parigi

Migration in Spain: Historical Background and 1 Current Trends

Aliyah to Israel: Immigration under Conditions of 1 Adversity

Tenures that Shook the World: Worker Turnover in $\quad 4$ Russia, Poland and Britain

Identification and Estimation of Causal Effects of 6 Multiple Treatments Under the Conditional Independence Assumption

The Rate of Return to Private Schooling

An Evaluation of Public-Sector-Sponsored

\section{Germany}

An Evaluation of Public Employment Programmes 6 in the East German State of Sachsen-Anhalt

Job Protection, Minimum Wage and Unemployment 3

Irish Migration: Characteristics, Causes and 1

Industry Wage Differentials Revisited: A

Longitudinal Comparison of Germany and USA

Residential Location and Youth Unemployment: 1

The Economic Geography of School-to-Work-

Transitions

Immigrant Assimilation and Welfare Participation: 1/3

Do Immigrants Assimilate Into or Out-of Welfare?

Employment and Wage Assimilation of Male First 3 Generation Immigrants in Denmark

Labor Supply and Matching Rates for Welfare

Characteristics

Estimation in a Duration Model for Evaluating

Matching Model with Uncertainty -

An Extension of Mortensen and Pissarides (1994)

Ownership or Performance: What Determines 1 
1979 - 1990: An analysis of the (West-)German multivariate failure times and unobserved heterogeneity

107 J. C. van Ours G. Ridder

J. Boone

J. C. van Ours

G. J. van den Berg

B. van der Klaauw

110 D. DeVoretz

C. Werner

111 V. Sorm

K. Terrell

L. Bellmann

T. Schank

113 R. Euwals

114 G. Brunello

A. Medio

115 A. Cigno

F. C. Rosati

116 C. Belzil

117 S. Bender

A. Haas

C. Klose

118 M. A. Shields

M. E. Ward

119 A. Lindbeck

D. J. Snower

120 P. T. Pereira

P. S. Martins

121 J. C. van Ours

122 D. Munich

J. Svejnar

K. Terrell

123 J. Hunt
Fast Track or Failure: A Study of the Completion

Rates of Graduate Students in Economics

Modeling Financial Incentives to Get Unemployed Back to Work

Combining Micro and Macro Unemployment

Duration Data

A Theory of Social Forces and Immigrant Second

Language Acquisition

Sectoral Restructuring and Labor Mobility:

A Comparative Look at the Czech Republic

Innovations, Wages and Demand for

Heterogeneous Labour: New Evidence from a

Matched Employer-Employee Data-Set

Do Mandatory Pensions Decrease Household

Savings? Evidence for the Netherlands

An Explanation of International Differences in

Education and Workplace Training

Why do Indian Children Work, and is it Bad for

Them?

Unemployment Insurance and Subsequent Job

Duration: Job Matching vs. Unobserved

Heterogeneity

IAB Employment Subsample 1975-1995.

Opportunities for Analysis Provided by the

Anonymised Subsample

Improving Nurse Retention in the British National

Health Service: The Impact of Job Satisfaction on

Intentions to Quit

The Division of Labor and the Market for

Organizations

Does Education Reduce Wage Inequality?

Quantile Regressions Evidence from Fifteen

European Countries

Do Active Labor Market Policies Help Unemployed Workers to Find and Keep Regular Jobs?

Returns to Human Capital under the Communist

Wage Grid and During the Transition to a Market

Economy

Why Do People Still Live in East Germany?
3

5

$2 / 00$

5

$2 / 00$

5

$2 / 00$

$1 / 00$

$1 / 00$

$1 / 00$

$2 / 00$

$2 / 00$

$2 / 00$

$2 / 00$

$2 / 00$

$2 / 00$

$2 / 00$

$2 / 00$

7

/00

$3 / 00$

$4 / 6$

4

$3 / 00$ 
Rational Poverty or Poor Rationality? The Take-up

125 F. Büchel

J. R. Frick

of Social Assistance Benefits

The Income Portfolio of Immigrants in Germany - $\quad 1 / 3$

$3 / 00$

Effects of Ethnic Origin and Assimilation. Or:

Who Gains from Income Re-Distribution?

126 J. Fersterer

R. Winter-Ebmer

Smoking, Discount Rates, and Returns to

Education

127 M. Karanassou

D. J. Snower

Characteristics of Unemployment Dynamics: The

Chain Reaction Approach

128 O. Ashenfelter

Do Unemployment Insurance Recipients Actively

Seek Work? Evidence From Randomized Trials in

D. Ashmore

O. Deschênes

129 B. R. Chiswick

M. E. Hurst

130 G. Brunello

S. Comi

C. Lucifora

Four U.S. States

The Employment, Unemployment and

Unemployment Compensation Benefits of

$1 / 3 \quad 3 / 00$

Immigrants

The Returns to Education in Italy: A New Look at $5 \quad 3 / 00$

the Evidence

Are Immigrants Favorably Self-Selected? An $\quad 1 \quad 3 / 00$

Economic Analysis

Hours and Wages in the Depression: British $7 \quad 3 / 00$

Engineering, 1926-1938

Paid and Unpaid Overtime Working in Germany and $1 \quad 3 / 00$

133 D. N. F. Bell

R. A. Hart

O. Hübler

W. Schwerdt

134 A. D. Kugler

G. Saint-Paul

135 A. Barrett

P. J. O'Connell

the UK

Hiring and Firing Costs, Adverse Selection and

3

$3 / 00$

Long-term Unemployment

Is There a Wage Premium for Returning Irish

1

$3 / 00$

Migrants?

136 M. Bräuninger

M. Pannenberg

Unemployment and Productivity Growth: An

3

$3 / 00$

Empirical Analysis within the Augmented Solow

Model

137 J.-St. Pischke

Continuous Training in Germany

$3 / 00$

138 J. Zweimüller

R. Winter-Ebmer

Firm-specific Training: Consequences for Job

Mobility

139 R. A. Hart

Y. Ma

Wages, Hours and Human Capital over the

Life Cycle

5

$3 / 00$

Education and Earnings Growth: Evidence from 11

European Countries

The Effects of Public Sector Sponsored Training on

Individual Employment Performance in East

$4 / 00$ 

both Worlds?

$\begin{array}{cl}145 & \text { M.-S. Yun } \\ 146 & \begin{array}{l}\text { T. K. Bauer } \\ \text { J.P. Haisken-DeNew }\end{array} \\ 147 & \begin{array}{l}\text { M. Belot } \\ \text { J. C. van Ours }\end{array}\end{array}$

Decomposition Analysis for a Binary Choice Model

Does the Recent Success of Some OECD

Microeconometric Evaluation of the Active Labour 6 Market Policy in Switzerland

The Duration of Immigrants' Unemployment Spells: $\quad 1 / 3 \quad 5 / 00$

155 J. Hansen

156 C. Dustmann Evidence from Sweden

Language Proficiency and Labour Market Per- 1

M. Jäntti

O. Raaum

E. Österbacka

Finland, Norway and Sweden Compared to the United States 

Models: The Case of the Self-Employed and the Increase in the Schooling Premium in the 1980's

161 V. Gimpelson

Public Employment and Redistributive Politics:

4

D. Treisman

Evidence from Russia's Regions

G. Monusova

162 C. Dustmann

M. E. Rochina-

Selection Correction in Panel Data Models: An

6

$6 / 00$

Barrachina

Application to Labour Supply and Wages

163 R. A. Hart

Y. Ma

Why do Firms Pay an Overtime Premium?

5

$6 / 00$

164 M. A. Shields

Racial Harassment, Job Satisfaction and Intentions

5

$6 / 00$

S. Wheatley Price

to Quit: Evidence from the British Nursing

Profession

165 P. J. Pedersen

Immigration in a High Unemployment Economy: 1

166 Z. MacDonald The Recent Danish Experience

M. A. Shields

The Impact of Alcohol Consumption on Occupa- 5 tional Attainment in England

167 A. Barrett

J. FitzGerald

Earnings Inequality, Returns to Immigration into Ireland

B. Nolan 